M. Abbaszade,

PhD in Economics, Doctoral candidate, Institute of Economics of ANAS, c. Baku, Azerbaijan Republic

ORCID ID: 0000-0002-1725-5777

DOI: $10.32702 / 2306-6806.2021 .4 .83$

\title{
THE MAIN DIRECTIONS OF REGULATION OF ACTIVITY OF THE FOOD MARKET
}

\author{
М. Аббасзаде, \\ к. е. н., докторант, Інститут економіки НАНА, м. Баку, Азербайджан
}

\section{ОСНОВНІ НАПРЯМИ РЕГУАЮВАННЯ АІЯАЬНОСТІ ПРОАОВОАЬЧОГО РИНКУ}

The main directions of regulation of the activity of the food market in modern economic conditions are considered in the article. The study of the issues related to the food problem in the article shows that, the process of strengthening the differences in the level of economic development between countries, monopolization of international markets and inequality processes of development factors are observed in modern market economy condition. Population around the world began to grow and forming a shortage of food products. This problem is becoming more global. From this point of view, it should be noted that the political and economic impact of developed countries are intensified under the globalization processes.

The analysis shows that the processes of limiting the possibility of meeting the demand of the population for food products by local sources in the globalized world are causes with negative results. This process also has a serious impact on economic security. Food security is an integral part of the state's national security system and creates favorable conditions for the stable life of society.

The article shows that the food market also serves members of society and the provide growing demands of the population for food products. The efficient formation of the food market creates favorable conditions for the protection of economic viability of producer and consumer segments, as well as expansion of relations between the city and the village.

Based on the analysis of the article, it was concluded that the activity of the food market must be regulated by the market mechanism with experience of developed world countries. For to achieve efficient operation of the food market must be regulate the food market through legal and economic mexanizms by the state. The food market should be provide as the main guarantor of social stability in society.

At the same time, in article identified the current problems related to the regulation of the activity of the modern food market, and also put forward proposals and recommendations for their elimination.

УСтатті розглянуто основні напрями регулювання функціонування продовольчого ринкув Сучасних економічних умовах. Вивчення в Статті питань, пов'язаних $з$ продовольчою проблемою, показує, що в сучасних умовах все частіше спостерігається процес посилення відмінностей у рівні економічного розвитку між, державами, монополізації міжнародних ринків, нерівності факторів розвитку. Уміру того, як кількість населення в усьому світі починає рости, спостерігається нестача продуктів харчування, проблема набуває все більш глобального характеру. Саме в цьому зв'язку Слід зазначити, що в міру посилення процесів Глобалізації відбувається посилення політичного та економічного впливу розвинених держав.

Проведений аналіз показує, що в умовах Глобалізації процеси обмеження можливостей задоволення потреб населення в продуктах харчування за рахунок місцевих, Ажерел призводять до негативних наслідків. Цей процес також має серйозний вплив на економічну безпеку. Продовольча безпека є склаАовою частиною системи національної безпеки держави і створює сприятАиві умови Аля Стабільної життедіяльності суспільства.

У Статті показано, що продовольчий ринок також Служить підвищенню рівня життя членів СуспільСтва, задоволенню зростаючих потреб населення в продовольстві і продуктах харчування. Ефективне формування продовольчого ринку Створює Сприятливі умови дАя збереження економічної самостійності продуктивного і споживчого сегментів, розширення зв'язків між містом і селом. 
У статті на основі аналізу зроблено висновок про те, що, як і в практиці розвинених країн світу, діяльність Продовольчого ринкУ Повинна регулюватися через ринковий механізм. ТУТ Продовольчий ринок повинен регулюватися, державою за, допомогою правових Та економічних механізмів, Аля, досягнення

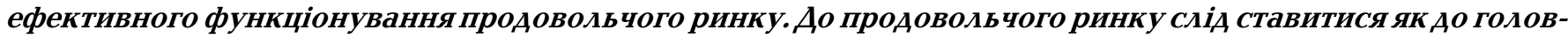
ного гаранта збереження соціальної стійкості в суспільстві.

У статті також визначено існуючі проблеми, пов'язані з регулюванням діяльності сучасного продоводьчого ринку, а також висунуто пропозиції та рекомендації щодо їх усунення.

Key words: state policy, integration, investment, economic integration, national economy, macro-economy.

Ключові слова: державна політика, інтеграчія, інвестичї, економічна інтеграчія, начіональна економіка, макроекономіка.

\section{INTRODUCTION}

In recent years, regulation of food market activity has been considered one of the main priority issues in developed countries. Every year a very serious economic policy is implemented in this direction all over the world. The analysis shows that the role of the food market in ensuring national economic security in the Azerbaijan Republic, as well including other post-soviet countries, are very high. That is why it is necessary to implement purposeful economic measures in this direction. The production of food products is a main element of the world standard of living. Consumption and nutrition has become the main economic and social category that characterizes the level of development of society and the standard of living of people. The population begins to grow, there has been a shortage of products and this problem has become increasingly global.

\section{ANALYSIS OF RECENT PUBLICATIONS ON THIS TOPIC}

Well-known scientists Volgina N.A., [3] Shakaraliyev A.S., [1] Mishenko V.V., [2] Abdullayev K.N. [6] and etc. in their works noted that very importance of regulation activity of food markets in modern economic condition. They examined in detail the role of the food market for ensuring the national security and economic grow th of the country.

In the beginning of the 21st century, the problem of food shortages is considered to be actual all over the world. Different international organizations are already emerging in this direction. This is the result of the fact that, taking into account the urgency of the problem, the UN Food and Agriculture Organization (FAO), was established and the mentioned issues constitute the priority direction of the organization's activities. Research shows that in $1950-1980$, a significant increase in the production of food products was observed on a global scale. Since the 90 s of the 21 st century, trends of decline in production and growth of prices in the food market to be observed. In modern times, production ecological food products has also become one of the actual problems. In modern economic conditions, the human health factor is more taken into account when producing food products.

Kuzmin D.V. in his works, noted that imported food products have a negative impact on the domestic food market and regulation role of the country in this area is important [5]. The rapid globalization of the system of international relations are observed with the strengthening of political and economic influence of developed countries on other countries. Thus, the processes of feeding the population in the conditions of globalization and limiting the possibility of meeting the demand for food products by the local sources lead to negative results. This process also has a negative impact on economic security. Food security as part of the state's national security system and creates conditions for the stable life activity of society.

As other post-soviet countries, appropriate measures are being taken for to ensure food security in the Azerbaijan Republic. Lack of adequate satisfaction of people's demand for food products causes serious dissatisfaction in every country. In addition, there are direct conditions for jeopardizing the economic and political sovereignty of the state. Therefore, in search of effective solutions to the food problem, a complex approach to the problem is required.

The problem of food safety is manifested in the power of differences between states in the level of economic development, in the monopolization of international markets and in the inequality of development factors. The states, which have large foreign exchange reserves as a producers of industrial products on the world market, stimulate the use of intensive technologies in agriculture, as well as in all areas of economy. At the same time, developed countries are subsidizing local producers of goods. They are implementing large-scale, targeted programs in the agrarian food sector by the financial support directed from the state budget. In addition, states effectively protect the national economy from the effects of foreign competition. The activity of developed countries in the international food market is more intensive [4].

In modern conditions, the problem of food manifests itself in more than three aspects. The first is due to the increase in the production of food products and the increase in the share of local production in the food market. Secondly, it reflects the ability of all segments of the population to obtain food products at affordable prices. The third aspect of the problem is the consideration of ecological problems in the production of food products. From an ecological point of view, the solution to the food problem involves the measures necessary to protect the environment and the production of safe food products for the health of the population.

\section{STATEMENT OF THE MAIN MATERIAL}

Studies show that the solution of the food problem directly depends on the formation of the food market and its organizational characteristics. Ensuring the country's food security depends significantly on the formation of the food market and its regulation in terms of strategic interests in the agrarian sector. In modern economic conditions, the food market is one of the most important and strategic components of the national economic system.

It should be noted that the food market has always existed and operated in a unique way in all economic systems. The price in the socialist economic system was regulated by the intervention of the state, not on the basis of supply and demand, which are the basic principles of market relations. This led to the restriction of independence of producers and consumers.

The activity of the food market is based on the interaction between the buyer and the seller, in other words, supply and demand. The market covers the sphere of exchange between producers and consumers of products, as well between countries within the framework of liberal economic boundaries [3].

In fact, the market is a category in which it is impossible to reproduce and deliver the product to the consumer in conditions of non-functioning. While it is not possible to reproduce the product, it is not possible to organize extensive re-production. 
Although the most recent and natural goal of economic activity is consumption, in all socio-economic systems, production is characterized as the most important sphere of the economy. Because the goods and services that meet human needs are created in the sphere of production. Any change in the sphere of production leads to the emergence of radical changes in other spheres of the national economy, including the sphere of distribution, exchange, consumption. That is why it is quite wrong to perceive the market as the only sphere of trade and sales.

Production directly affects consumption by creating material benefits in the market. It is known that production is carried out under conditions of limited resources, and this process is significantly dependent on the market conjuncture. At the same time, as the demand and income levels of the members of the society increase, the volume of production increases rapidly.

There are also foreign economic relations, including import, trade and other channels to pay for the provision of the population with special food products. All imported products in the food market are obtained by paying a fee.

The volume, structure and quality of production depend directly on the volume, range of demand. ?n the market. All commodity producers, workers of trade and service spheres are more interested in the production and sale of food products which had high demand in the markets.

Thus, as already mentioned, the food market is the most important component of the market system. However, along with this, the food market has its own unique economic essence. Thus, the material basis of the food market is the production of agricultural products. Since the agrarian sector has its own specific features, the process of its formation should be taken into account.

The food market, in essence, serves to meet the needs of the members of the society for food and food products. Thus, the food market also operates on the basis of supply and demand. The food market reflects organizational-economic and social relations between producer and consumer. Thus, the problem of food has existed in all periods of the development of society.

As is known, the development of the agrarian sector, like all sectors of the economy, was under the control of the state in the centralized socialist economy. During the soviet period, the state order and procurement system was a priority in the agrarian field. State structures almost controlled the agrarian sector and economic activity as a whole. They contributed to the purchase of agricultural products, the supply of agricultural enterprises with material and technical resources and the distribution of resources. However, in the conditions of centralized planning, the food market was not provided only with domestic resources. Although the provision of the food market by the of local production was a priority direction of the state's agrarian policy, important food products were provided by the import channels.

In the soviet economic system, the price relationship between supply and demand in the food market in the Azerbaijan Republic, including other post-soviet countries, was determined in a centralized manner. Conducting marketing research on the food market, research on the market conjuncture were not generally considered. The state order played a special role in the food market. In the soviet economic system, the quality of agricultural products, the range and the timely delivery of products to the required places were controlled directly by the central regional authorities [1].

As it appears from the research, the soviet economic system has operated for nearly 70 years. After the collapse of the former USSR, a crisis began in the national economy of all newly independent countries. The main reason for this was a violation of the economic relations between the countries of all production. As a result of this, all relations formed in the production, processing, supply, transportation, sales systems have been broken. As a result, there were significant problems in the agricultural production of countries.

In the Azerbaijan Republic, as well in other post-soviet countries, decline volume of food production in the beginning of the $90 \mathrm{~s}$. are observed. Because national food market was not provided fully by domestic production. Only imported products from foreign countries began to play a key role in providing citizens with food products in the domestic food market. In the post-soviet countries this led to the payment of up to $90 \%$ of the population's demand for food products by imports channel. These processes also jeopardized the economic independence of the Azerbaijan Republic, also for other post-soviet countries [6].

The activity of the food market at all times affects the volume of trade in agricultural products and processing industrial products. The expansion of entrepreneurial activity depends requirement for agricultural products in domestic food market.

The main priority direction of ensuring the food market by the local production is the alignment of the volume of agricultural and food production with the needs of the population. The development of the region should ensure effective interaction between agriculture, processing enterprises and agro services.

The food market of Azerbaijan Respublic serves to meet the needs of the members of the society for agricultural and food products. The current situation in the food market, as well as any changes in the market conjuncture, have a direct impact on social stability in society. For example, the change in prices of products in the food market also affects the standard of living of the population. In general, the changes in the food market also affect the level of economic development of the state.

The food market also reflects the trade w th agricultural and food products. The food market also to meet the growing demands of the population on food products. Food market creates favorable conditions for the protection of economic interest of producer and consumer segments.

In general, the formation of an efficient food market in the Azerbaijan Republic is significantly dependent on the efficient organization of the agribusiness structure. Agribusiness in the food market is directly related to the formation of the sphere of efficient wholesale and retail sales. Trade in wholesale and retail food products is an integral part of the commodity circulation process. As is known, in the food market, products are not always delivered directly, from the manufacturer to the consumer. The experience of developed countries shows that agricultural and food products enter the food market mainly through wholesale trade organizations. From there, it is delivered to consumers through retail sales networks. In this regard, wholesale and retail trade organizations play a key role in the development of food market [3].

Trade organizations engaged in the wholesale of agricultural products perform a number of functions in this regard. Thus, trade organizations engaged in wholesale of food products influence the production, while at the same time impacting the range of trade. As a result, it provides its retail network with agricultural and food products. Wholesale trade organizations create favorable conditions for the storage and delivery of food products to consumers by organizing the infrastructure of the food market.

Entrepreneurs working in agriculture sector sell their products in domestic markets. Agricultural producers prefer to meet more specific demand. This is directly related to the independent nature of the sales network and the market. Entrepreneurs operating in the agrarian sector sell the products produced by agricultural producers through a stable market. And the rest of the product is a source of reserve for personal consumption and further production.

Prices in the domestic food market in the Azerbaijan Republic, also including in other post-soviet countries are formed on the basis of demand and supply for food products. The level of price in the food market significantly affects 
the incomes of producers, as well as the standard of living of consumers. The formation of a freely regulated food market is significantly dependent on the economic policy of the state and the purchasing power of consumers.

\section{CONCLUSION}

In the experience of developed world countries, the activity of the food market, as a other economic structures, is regulated by the market mechanism. For to achieve effective functioning of the food market must be regulated by the state through legal and economic mechanisms. In developed countries, the food market is treated as the main guarantor of social stability in society. For example, the legislative acts adopted in the Republic of Azerbaijan on the establishment and protection of the state-secured internal market constitute the legislative basis of regulation in this area.

Ensuring the independence of food producers, the development of various forms of property, causes to stabilize the level of prices. In the Azerbaijan Republic is planned to improve the quality indicators of food products in the next years and to expand the activity of the food market in general.

Sharp increase price of energy resources in the international world market, negative trends in the financial market of leading countries, as well as an increase of population around the world are observed. This is condition provide increase of demand for food products.

Recently, prices for basic food products have started to increase in the world market. This directly influenced to the domestic food market of the importing countries. Food shortages have already become a real threat in some countries in the world. According to the United Nations Food and Agriculture Organization (FAO), if the annual growth of food production in 1950-1985 years amounted to 30 million tons, in $1985-1995$ years to 12 million tons. This is indicator will be only 9 million tons by 2030. Analysis shows that the volume of food production in the world has been declining in recent years [5]. Effective organization of food market activity will play an important role for ensuring economic independence of the Azerbaijan Republic, as well other post-soviet countries and improving the standard of living of the population. Therefore, it is necessary to carry out appropriate measures in this direction at the state level.

Мітература:

1. Шакаралиев А.Ш. Экономическая политика государства: торжество устойчивого и стабильного развития. - Баку, Изд. Victory, 2011. - 542 с.

2. Мищенко В.В. Экономика регионов. - Москва: ИК Аналитика, 2012. - 290 с.

3. Волгина Н.А. Международная экономика. - Москва: Эксмо. - 2009. - 345 с

4. Ширай В.И. Мировая экономика и международные экономические отношения. - Москва: Издательских дом Аашков и К. 2003. - 528 с.

5. Кузьмин А.В. Национальная конкурентоспособность, глобальная нестабильность и макроэкономическое равновесие. - Москва: Наука, 2015. - 222 с.

6. Абдуллаев К.Н. The role of international transport corridors for providing sustainable development of national еconomy "Современная экономика и управление: подходы, концепции, модели", Международная научнопрактическая конференция, Российской Экономический Университет имени Г.В. Плеханова, Саратовский социально-экономический институт. - Саратов: ИзАво Наука, 2016. - С. 8-9.

\section{References:}

1. Shakaraliyev, A.Sh. (2011), Ekonomiceskaya politika qosudarstva: torjestva ustoycivoqo i stabilnoqo razvitiya [Economic policy of state: triumph of sustainable and stable development], Victory, Baku, Azerbaijan.
2. Mishenko, V.V. (2012), Ekonimika regionov [Economy of regions], IK Analitika, Moskva, Russia.

3. Volqina, N.A. (2010), Mejdunarodnaya ekonomika [International economics], Eksmo, Moskva, Russia.

4. Shiray, V.I. (2003), Mirovaya ekonomika i mejdubarodnie ekonomiceskie otnosheniya [World economy and international economic relations], Moskva, Dashkov and K, Moskva, Russia.

5. Kuzmin, D.V. (2015), Nasionalnaya konkurentosposobnost, globalnaya nestabilnost i makroekonomiceskie ravnovesii [National competitiveness, global unstability and macroeconomic balance], Nauka, Moskva, Russia.

6. Abdullayev, K.N. (2016), "The role of international transport corridors for providing sustainable development of national economy", Sovremennaya ekonomika I upravlenie: podxodi, konsepsii, modeli. Mejdunarodnaya naucnoprakticeskaya konferensiya [Modern economy: approach, conceptions, models. International scientific-practical conference], Rossiyskoy Ekonomiceskiy Universitet imeni Q.V.Plexanova (Moscow), Russian Economic University after named Q.V.Plexanova, Saratovskiy Sosialno-Ekonomiceskoy Institut (Saratov), Saratov Social Economic Institute, Saratov, Russia, pp. 8-9.

Cтаття надійшла до редакиіï 25.03.2021 p.

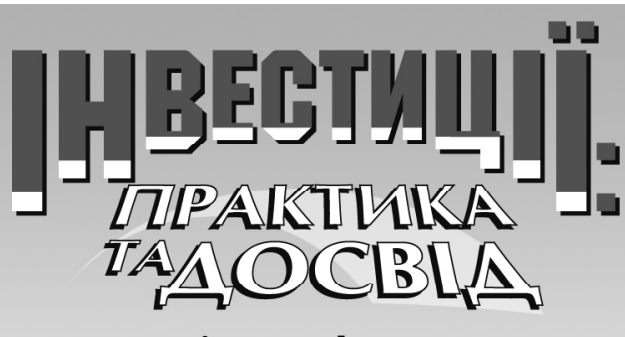

www. investplan.com.ua

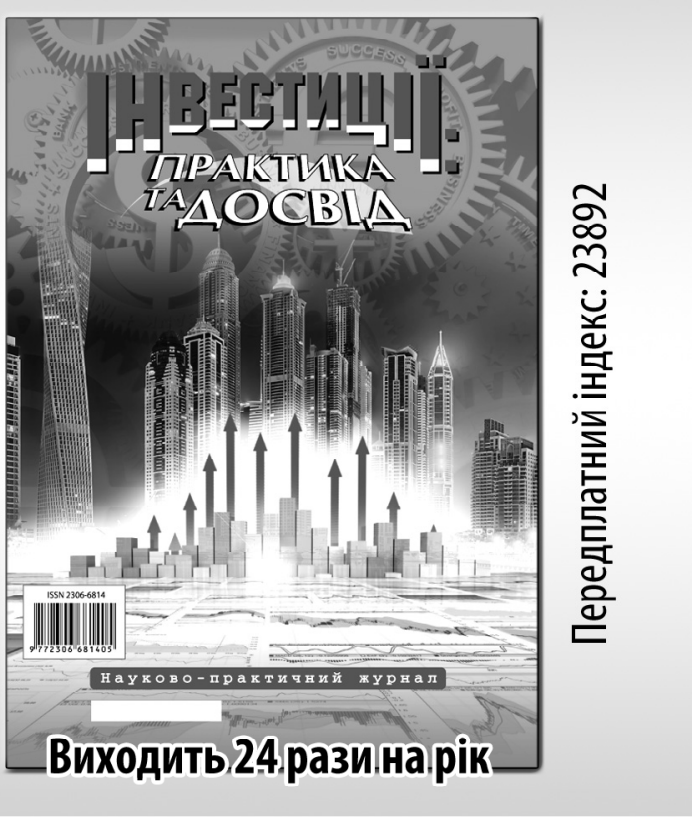

Журнал включено до переліку наукових

фахових видань України (Категорія «Б») 3

\section{ЕКОНОМІЧНИХ НАУК та ДЕРЖАВНОГО УПРАВЛІННЯ}

(Наказ Міністерства освіти і науки України № 886 від 02.07.2020)

Спеціальності - 051, 071, 072, 073, 075, 076, 281, 292 